\title{
High cervical spine spondylodiscitis management and literature review
}

André Luis Sebben ${ }^{1,2 *}$, Xavier Soler Graells ${ }^{1,2}$, Marcel luiz Benato ${ }^{2}$, Pedro Grein Del Santoro ${ }^{2}$, Álynson Larocca Kulcheski ${ }^{2}$

${ }^{1}$ Orthopedics and Traumatology Service, Hospital de Clínicas, Universidade Federal do Paraná (UFPR), Curitiba, PR, Brazil

${ }^{2}$ Orthopedics and Traumatology Service, Hospital do Trabalhador, UFPR, Curitiba, PR, Brazil

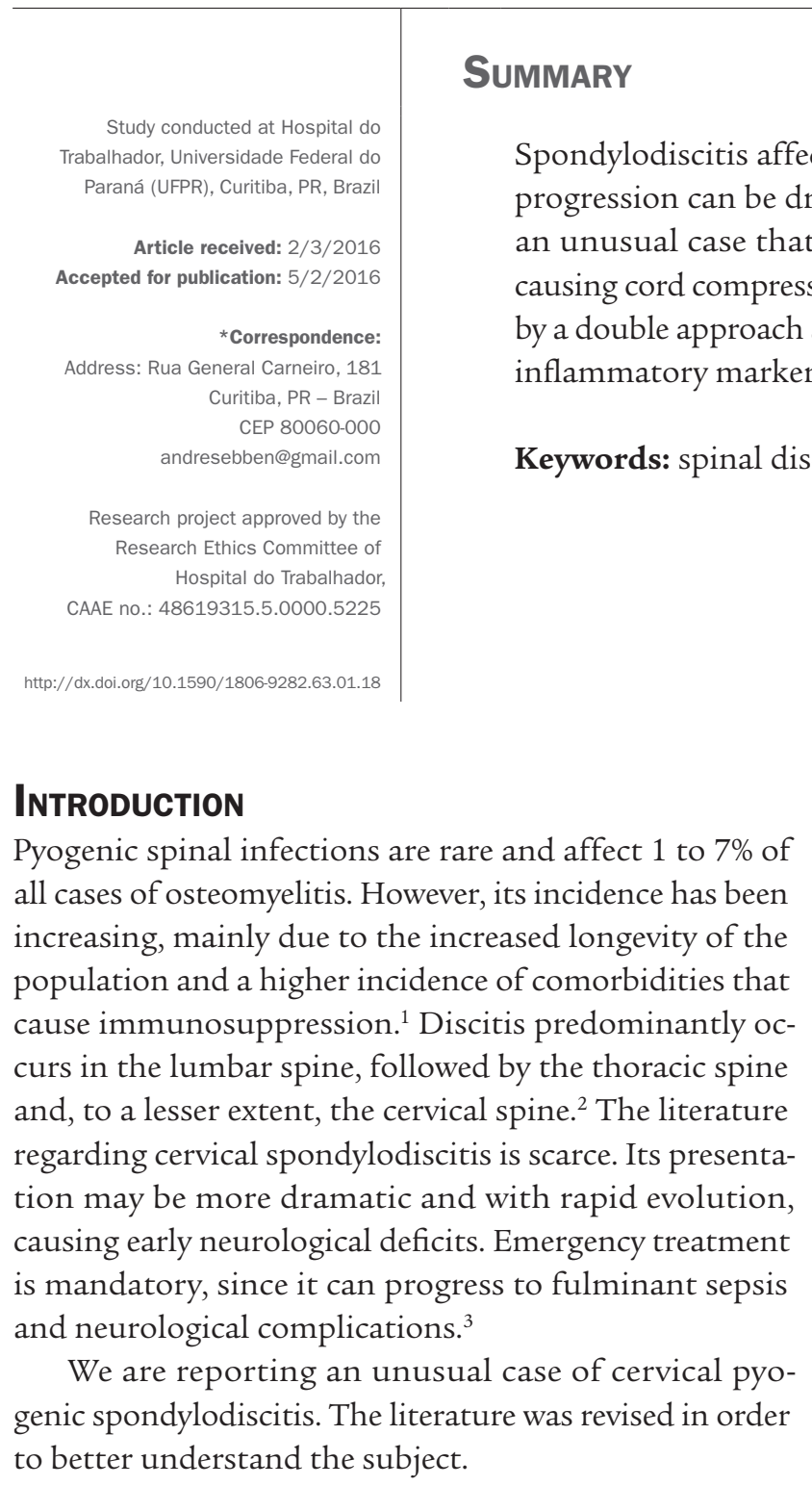

\section{Case report}

Male patient, 59 years old, farmer. The initial complaint was intense neck pain for 2 months with progressive worsening. This was associated with constitutional symptoms including weight loss of $10 \mathrm{~kg}$ in 45 days, loss of appetite, fever, adynamia, and night sweats. Upon physical examination, the patient was emaciated, febrile $\left(38.3^{\circ} \mathrm{C}\right)$, prostrate, and presented intense pain upon anterior cervical palpation with an antalgic posture in semiflexion. Passive and active cervical mobilization was painful. Muscle strength, deep tendon reflexes, and sensitivity in the limbs were preserved.

Laboratory tests on admission showed 8,200 leukocytes with $2 \%$ Auer rods, erythrocyte sedimentation rate (ESR) of $100 \mathrm{~mm} / \mathrm{h}$ and c-reactive protein (CRP) of 35 $\mathrm{mg} / \mathrm{L}$. Blood culture from two samples showed no growth of microorganisms.

$\mathrm{X}$-ray and computerized axial tomography of the cervical spine showed lytic lesions between $\mathrm{C} 2$ and $\mathrm{C} 3$. The nuclear magnetic resonance imaging (NMR) showed signs suggestive of spondylodiscitis in C2-C3 associated with the presence of a massive epidural abscess compressing the ventral surface of the spinal cord, as well as involvement of paravertebral and prevertebral soft tissues (Figure 1). Bone scintigraphy ruled out an expansive tumor process and confirmed the NMR findings.

A decompressive anterior cervicotomy was performed at C2-C3 level, with the presence of purulent material. A discectomy was performed and a tricortical structural iliac graft was inserted. After 2 weeks, a posterior cervical arthrodesis was performed with C2-C3 sublaminar wiring associated with insertion of a posterior iliac tricortical graft block (Figures 2 and 3). Examinations showed the 


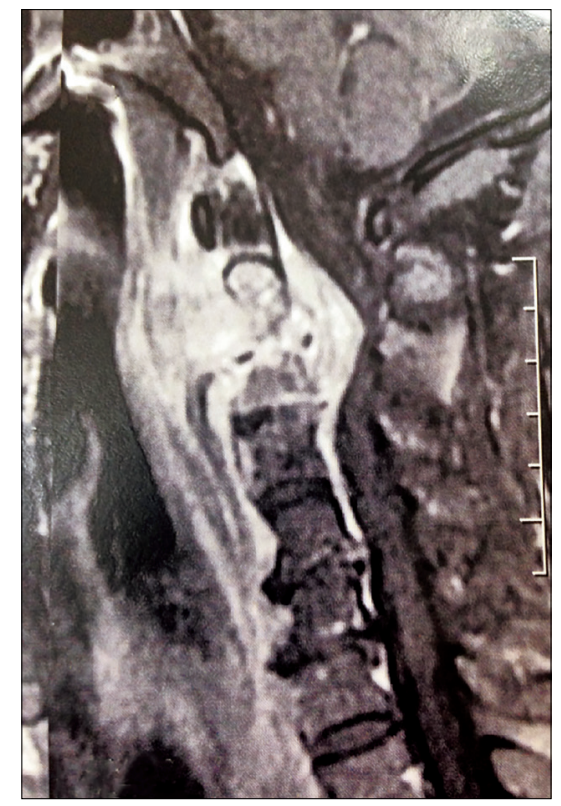

FIGURE 1 Cervical NMR image showing signs of spondylodiscitis in C2-C3 with spinal cord compression and epidural abscess.

growth of multisensitive Staphylococcus aureus and anatomopathological examination confirmed inflammation.

In accordance with the sensitivity spectrum of the germ, oxacillin $500 \mathrm{mg}$, intravenous, every 4 hours was given for 3 weeks, followed by cefalexin $500 \mathrm{mg}$, peroral, every 6 hours for another 5 weeks, with a total of 8 weeks of antibiotic therapy.

The patient progressed satisfactorily with improvement of the pain, as assessed using a visual pain scale, which was 10 in the preoperative period and fell to 2 on the $5^{\text {th }}$ day after surgery. The Oswestry 2.0 questionnaires were also applied before and after surgery, with $49 / 50$ points in the preoperative period, ranking as an invalid, and 4/50 in the postoperative period, showing an excellent post-surgical outcome. The patient was discharged after three weeks without complaints and with laboratory examinations that showed a decrease in inflammatory markers. Six weeks after surgery, the patient was still using a Philadelphia cervical collar, and already showed signs of osseointegration of the graft. The patient remained asymptomatic.

\section{Discussion}

Cervical spondylodiscitis is rare, given that most vertebral abscess and cases of discitis occur in the thoracic and lumbar spine. The annual incidence varies from 0.5 to 2.5 cases per 100,000 inhabitants. Spondylodiscitis is the primary manifestation of hematogenous osteomyelitis in patients over 50 years of age, representing 3 to $5 \%$ of all cases of osteomyelitis. ${ }^{4}$
Pathogens can affect the spine by three routes: hematogenous, external inoculation or contiguity.

The arterial hematogenous route is the predominant one, enabling the infection to be disseminated from distant sites. ${ }^{5}$

Although a broad spectrum of microorganisms have been identified (bacteria, mycobacteria, fungi and parasites), a monobacterial etiology predominates, with $S$. aureus being the most common. ${ }^{6}$ The present case reiterates the higher prevalence of this germ in the literature.

The main risk factors include use of intravenous drugs and comorbidities such as diabetes and terminal chronic renal failure. ${ }^{6}$ We found no risk factors in the case reported, which makes it even more atypical.

As shown in the literature, ${ }^{5} \mathrm{NMR}$ is the most sensitive (93-96\%) and specific (92.5-97\%) test for the early detection of spondylodiscitis. In most cases, it can differentiate between pyogenic infections, neoplasms, and tuberculosis.

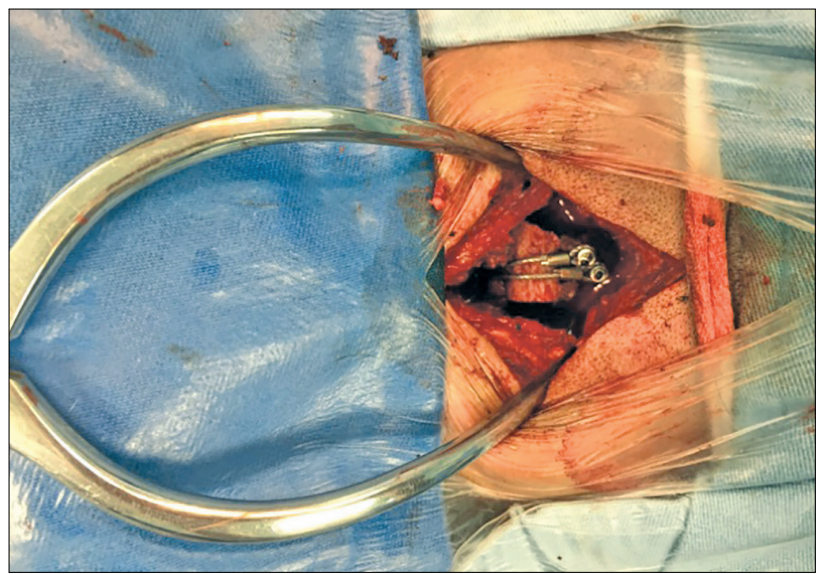

FIGURE 2 Transoperative image of posterior fixation with the iliac graft.

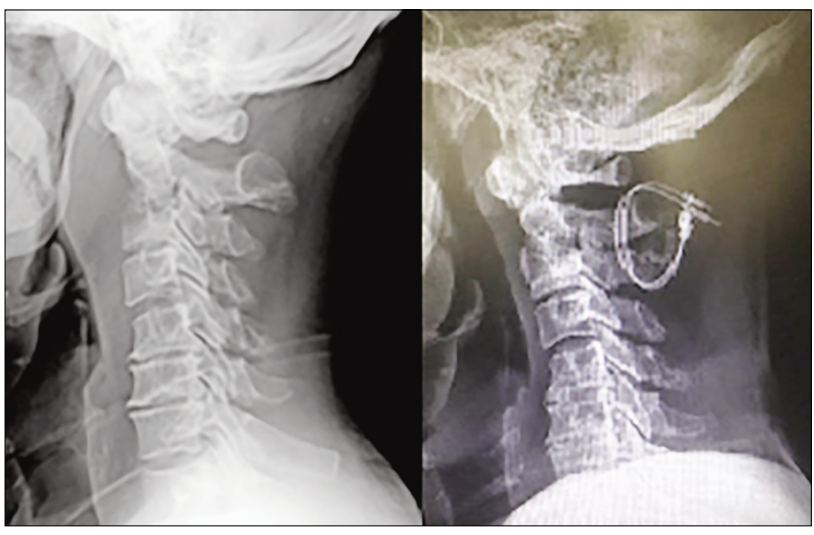

FIGURE 3 Profile image of the pre and postoperative radiography. 
Furthermore, it can define the paravertebral and epidural spaces better. ${ }^{7}$ This complementary examination was used to diagnose a case that progressed slowly and was fundamental for the diagnostic definition, treatment and resolution of the case.

In order to direct the antibiotic therapy, a percutaneous biopsy, which is a safe and minimally invasive procedure, may bey performed. If the first sample is negative, some experts recommend taking another. ${ }^{8}$ Friedman reported $50 \%$ positivity in cultures produced from percutaneous biopsies. Surgical debridement is reserved for patients who present abscesses and neural compression and need to have their spine stabilized, a fact that occurred in our case. Other indications include debridement of devitalized tissue and removal of infected implant material. Specific antibiotics should be administered for 8 to 12 weeks after surgery, according to the results of the culture. Infections in most of the patients are resolved using this approach. ${ }^{9}$

Classically, the standard treatment was corpectomy and placement of structured grafts without the use of the implant material. Currently, most surgeons have preferred techniques that provide greater stability to the targeted site using implant material in patients treated for spondylodiscitis. There is preference for the posterior route in the cervical spine in order to avoid the main complications, which include graft migration, failure of the synthesis material and esophageal fistula. Several authors have reported no complications related to the use of these implants. ${ }^{10}$

Our patient was treated according to this protocol and recovered satisfactorily.

\section{Conclusion}

Although cervical spondylodiscitis is a rare disease, it is a diagnosis that should not be overlooked in patients who have indolent neck pain associated with constitutional symptoms. Early diagnosis and initiation of therapy are the only means of avoiding disease progression, thus preventing patients from having sequelae that are often irreversible.

\section{Resumo}

Espondilodiscite da coluna cervical alta: manejo e revisão da literatura

A espondilodiscite, que acomete a coluna cervical, é a de localização mais rara. Pode ter uma evolução dramática, inclusive causando tetraplegia e óbito. Apresentamos um caso atípico que evoluiu com lesões osteolíticas entre C2 e C3, causando compressão medular e abscesso epidural. O paciente foi submetido a tratamento cirúrgico por dupla abordagem e evoluiu bem, sem déficits neurológicos e com melhora dos marcadores inflamatórios. Revisamos a literatura vigente sobre o assunto.

Palavras-chave: doenças da coluna vertebral, cervicalgia, discite.

\section{References}

1. Kulcheski AL, Graells XS, Benato ML, Santoro PG, Sebben AL. Espondilodiscite fúngica por Candida albicans: um caso atípico e revisão da literatura. Rev Bras Ortop. 2015; 50(6):739-42.

2. Baker AS, Ojemann RG, Swartz MN, Richardson EP. Spinal epidural abscess N Engl J Med. 1975; 293(10):463-8.

3. Schimmer RC, Jeanneret C, Nunley PD, Jeanneret B. Osteomyelitis of the cervical spine: a potentially dramatic disease. J Spinal Disord Tech. 2002; 15(2):110-7.

4. Jensen AG, Espersen F, Skinhøj P, Rosdahl VT, Frimodt-Møller N. Increasing frequency of vertebral osteomyelitis following Staphylococcus aureus bacteraemia in Denmark 1980-1990. J Infect. 1997; 34(2):113-8.

5. Cottle L, Riordan T. Infectious spondylodiscitis. J Infect. 2008; 56(6):401-2

6. Kulowski J. Pyogenic osteomyelitis of the spine: an analysis and discussion of 102 cases. J Bone Joint Surg. 1936; 18(2):343-64.

7. Hopkinson N, Stevenson J, Benjamin S. A case ascertainment study of septic discitis: clinical, microbiological and radiological features. QJM. 2001; 94(9):465-70.

8. Rankine JJ, Barron DA, Robinson P, Millner PA, Dickson RA. Therapeutic impact of percutaneous spinal biopsy in spinal infection. Postgrad Med J. 2004; 80(948):607-9.

9. Cebrián Parra JL, Saez-Arenillas Martín A, Urda Martinéz-Aedo AL, Soler Ivañez A, Agreda E, Lopez-Duran Stern LL. Management of infectious discitis. Outcome in one hundred and eight patients in a university hospital. Int Orthop. 2012; 36(2):239-44

10. Suess O, Weise L, Brock M, Kombos T. Debridement and spinal instrumentation as a single-stage procedure in bacterial spondylitis spondylodiscitis. Zentralbl Neurochir. 2007; 68(3):123-32. 